University of Nebraska - Lincoln

DigitalCommons@University of Nebraska - Lincoln

To Improve the Academy

Professional and Organizational Development Network in Higher Education

1996

Section III: Organizational Development

Follow this and additional works at: https://digitalcommons.unl.edu/podimproveacad

Part of the Higher Education Administration Commons

"Section III: Organizational Development" (1996). To Improve the Academy. 366.

https://digitalcommons.unl.edu/podimproveacad/366

This Article is brought to you for free and open access by the Professional and Organizational Development Network in Higher Education at DigitalCommons@University of Nebraska - Lincoln. It has been accepted for inclusion in To Improve the Academy by an authorized administrator of DigitalCommons@University of Nebraska - Lincoln. 


\section{Section III:}

\section{Organizational Development}

This section, in which the authors discuss institutional programs or approaches to teaching change, has three parts. The first area, focused on campus environment and culture, includes Wright's discussion of moving toward a system which rewards teaching, and Dove's and Wills' arguments for transforming faculty into an "agile" workforce. In the second area, funding, Everley and Smith provide information on an essential and often overlooked aspect: how to continue programs begun on soft money. And, finally, there are four articles focused on programs which have been able to change their campus teaching cultures. Lieberman and Reuter detail their technology-pedagogies institutes and the effects on faculty who participate in them. Harper reports on the results of creating a community of conversation among teacher-scholars. Sweidel discusses the effects of a project that included peer observation, student interviews, and collegial discussion. Cox reports result from a multi-year project that used a departmentbased approach to creating teaching portfolios. 